ELORE (ISSN 1456-3010), vol. 15 - 2/2008.

Julkaisija: Suomen Kansantietouden Tutkijain Seura ry.

[http://www.elore.fi/arkisto/2_08/hol2_08.pdf]

\title{
JÄLLEENRAKENTAMISEN NARRATIIVIT JA NIIDEN MUOTOUTUMINEN SUOMEN LEHDISTÖSSÄ 1944-1945
}

\author{
$\underline{\text { Antero Holmila }}$
}

\section{JOHDANTO}

Vuonna 2002 Kansallisteatteri juhlisti 100-vuotista taivaltaan esittämällä 1950-luvulle sijoitetun version Aleksis Kiven Nummisuntareista. Teatterikriitikko Kirsikka Moring (HS 2002, B9) kysyi Helsingin Sanomissa 27.9.2002: "Miksi juuri 50-luku? [...] haluttiinko viitata jälleenrakentamisen ajan yhtenäiskulttuurïn ja Suomen aitona poreilevaan maalaisuuteen, elossa olevaan käsityöläisyyteen?” Jussi Tossavainen puolestaan kirjoitti Helsingin Sanomien kulttuuripalstalla 1.11.2006 Lahden kaupunginteatterin Metsäoopperasta seuraavaa:

Päähenkilö Ilmari [...] tapaa menneen aaveet, kuolleet äitinsä ja isänsä. Heidän historiansa kerrataan kuvaelmina ja takautumina. Samalla käydään läpi kansan kollektiivista muistia ja kokemusta [...] Koetaan yhdessä sodan kauhut ja maan jälleenrakentaminen sotakorvauksineen [...] kansan parissa ollaan, työ on kovaa ja leipä pyhää [... ] Juuriltaan vieraantuneille citynuorille tämä voisi olla kelpo historian oppitunti. (HS 2006, C4.)

Molemmissa esimerkeissä jälleenrakennus ei ainoastaan tule annettuna vaan myös nostalgisena kulttuurisena konstruktiona kansan yhteisestä kokemuksesta. Näissä arvosteluissa on vaikea erottaa, puhutaanko oikeastaan jälleenrakentamisesta vai 2000-luvun arvoista. Työ oli kovaa ja leipä pyhää, mutta toiminnan keskipisteenä oli kansa, joka edusti "yhtenäiskulttuuria", toisin kuin kirjoitusajankohtien globalisoitunut ja fragmentoitunut, digitaalitekniikan avulla sementoitu, tietoyhteiskunta (ks. esim. Eskola 1987, 147).

Tässä artikkelissa käsittelen Suomen jälleenrakentamista, koska se voidaan ymmärtää osaksi suomalaista kulttuuriperintöä, kuten yllä esitetyt kaksi esimerkkiä osoittavat. Jälleenrakennuksella tarkoitan ensisijaisesti aikaa syyskuun 1944 jälkeen, jolloin Lappia lukuun ottamatta rauha palasi maahan. On huomattava, että jälleen- 


\section{JälLEENRAKENTAMISEN NARRATIIVIT JA NIIDEN MUOTOUTUMINEN SUOMEN LEHDISTÖSSÄ 1944-1945}

rakennus korostaa ensisijaisesti aikalaiskokemusta - ajatusta palata aikaisemmin vallinneeseen tilaan. Ymmärrettiin, että sodassa vaurioita kärsineet henkiset ja materiaaliset saavutukset oli rakennettava uudestaan. Käytän termiä "jälleenrakennus", enkä esimerkiksi "uudelleen rakennus", koska ulkopolitiikkaa lukuun ottamatta maa ja kansakunta rakennettiin sota-aikaa edeltäneiden toimintamallien ja uskomusten mukaan, joskin hieman erilaisilla painotuksilla ja korostuksilla.

Lähestyn aihettani (uus)historioitsijan näkökulmasta, painottaen kerronnan tärkeyttä merkityksen luomisen apuvälineenä. En kuitenkaan halua unohtaa historiallisen kontekstin merkitystä, sillä kerrontaa, aivan kuten diskursseja, ei voida tuottaa eikä ymmärtää ilman kontekstia. Uskon, että kerronnan lausumat ovat merkityksellisiä vain, jos tiedetään, mihin menneisyyden tapahtumaan ne liittyvät (Wodak 1996, 19). Muuten on vaarana, että tekstit jäävät irrallisiksi osiksi historiasta tai yhteiskunnasta, mitä ne eivät ole. Lisäksi on todettava, että konteksti on myös välttämätön analyysin tulosten ymmärtämiseksi. Uutistapahtumat ovat noin 60 vuoden takaa, joten voi tuskin olettaa, että lukijoilla olisi selkeä kuva kaikista tapahtumista, niiden kulusta ja taustoista. (Mäkilä 2007, 16.)

Tätä jälleenrakennuskertomusta avatessani systemaattisen tutkinnan kohteena, eräänlaisena runkoaineistona, ovat olleet maan johtava sanomalehti, poliittisesti sitoutumaton liberaali Helsingin Sanomat, maan johtava ajankohtaisista tapahtumista kirjoittanut porvarillinen Suomen Kuvalebti sekä naisille suunnattu porvarillinen Kotiliesi. Tutkinnan kohteena ovat olleet pääkirjoitusten lisäksi myös uutiset, pakinat, katsausartikkelit ja mielipidepalstat. En ole rajoittanut aineistoani ainoastaan pääkirjoituksiin, koska ensinnä ne eivät ole lehtien (kuten Helsingin Sanomien) luetuinta aineistoa ja toisekseen julkinen keskustelu on laajempaa kuin pääkirjoitusten mielipiteet, jotka ovat viime kädessä lehden toimittajien laatimia. Vaikka pääkirjoitukset ovatkin avartavia, eivät ne kuitenkaan voi käsitellä kaikkia ajankohtaisia kysymyksiä, kuten esimerkiksi rintamalta kotiin palaavan miehen ja tämän vaimon kohtaamia ongelmia. Lisäksi olen selannut läpi (mikrofilmiltä) sosialidemokraattien pää-äänenkannattajan Suomen Sosialidemokraatin sekä kansallismielisen mutta poliittisen kentän äärilaitoja vastustaneen Suomalainen Suomi-aikakausilehden. Jotta analysoimani sanomalehtikeskustelu ei rajoitu ainoastaan pääkaupungin ja Kanta-Suomen sanomalehtiin, olen valinnut mukaan ennen talvisotaa Viipurissa ilmestyneet sosialidemokraattisen Kansan Työn, joka ilmestyi sodan jälkeen Lappeenrannassa, sekä Maalaisliiton Karjalan Sanomat, joka sodan jälkeen ilmestyi ensin Lahdessa ja vuoden 1945 lopulta Helsingissä nimellä Maakansa. Kanta-Suomen lehdistä olen tarkastanut Edistyspuolueen Kalevan (Oulu) ja Maalaisliiton Savon Sanomat (Kuopio). Näin ollen runkoaineistoa täydentävä materiaali kattaa (radikaalimpia laitoja lukuun ottamatta) poliittisen kentän päälinjat sekä myös "evakkolehdistöä".

Pertti Alasuutari on tutkinut tapaa, jolla lehdistö tuotti ja muovasi väestöä sodanjälkeisessä toisessa tasavallassa. Hänen mukaansa "[a]atteisiin ja moraalisiin periaatteisiin vetoaminen oli pinnalla. Ensinnäkin maa oli vasta ollut sodassa, joka lujitti kansallista yhteenkuuluvuuden tunnetta, ja jonka aikana kansakunta pyrittiin pitämään koossa vetoamalla eettisiin periaatteisiin, kuten yhteisvastuuseen.” (Alasuutari 1996, 107). Tämä käy ilmi myös omassa tutkimuksessani, jossa kuvailemani 


\title{
Antero Holmila
}

narratiivit "selviytyminen/yhteistyö", "uhrautuminen/velvollisuuden täyttäminen" ja "itsehillintä" perustuvat aikalaiskirjoituksissa toistuvasti esiintyneille tekstuaalisille valinnoille. Seuraavassa esittelen artikkelini teoreettisen viitekehyksen sekä sen historiallisen kontekstin, joka osaltaan muokkasi käsittelemiäni teemoja.

\section{MERKITYKSEN KONSTRUOINTI KULTTUURIN TUTKIMUKSESSA}

Lähestyn aihetta käyttäen apunani yhdysvaltalaisen sosiologin Anne Kanen teoriaa, jossa symboliikan ja kerronnan tutkimisella on keskeinen asema selvitettäessä kulttuurin konstruktiivista luonnetta. Kanen mukaan merkityksillä on konstruktiivinen luonne, koska ainoastaan rakennettujen merkityksien avulla voidaan sovittaa yhteen hyvinkin erilaisia yhteiskunnallisia, sosiaalisia ja kulttuurisia arvoja (ks. Kane 2000, 311-330).

Vaikka jälleenrakennuksen aika nykyisellään symboloi yhtenäiskulttuuria, on muistettava, että historiallisessa kontekstissa rauhaan palaava Suomi oli huomattavasti monitahoisempi kuin nykymedian (usein) anakronistiset menneisyydentulkinnat kertovat. Sodan jälkeen ei ollut ollenkaan varmaa, pystyisivätkö suomalaiset yhteisesti jälleenrakentamaan maan. Sodan päättyminen esimerkiksi mahdollisti pitkään tukahdutettujen voimien ja ajatusmallien esiinmarssin, mikä puolestaan tarkoitti asenteiden ja mielipiteiden monipuolistumista, kärjistymistä ja kokonaisuudessaan yhteiskunnan pluralisoitumista (erityisesti verrattuna sota-aikaan). Sodanjälkeisessä "aallonpohjassa" yhteiskunnallisen konfliktin vaara ei ollut mahdottomuus. Olavi Paavolaisen Synkkä Yksinpubelu kertoo nopeasta aatemaailman pluralisoitumisesta selväsanaisesti:

\begin{abstract}
26.9. [1944] Hella Vuolijoki, Mauri Ryömä, K. H. Wiik ja Cay Sundström mainitaan vapaaksi päässeiden poliittisten vankien joukossa [...] 3.10. Illalla tapaan pari vankilasta vapautunutta "kulttuuriradikaalia" [...] 5.10 Illalla on Työväentalolla poliittisten vankien vastaanottojuhla. Valitettavasti tilaisuus kuitenkin on loppuunmyyty [...]13.10. Paasikiven johdolla perustetaan yhdistys Suomen ja Neuvostoliiton välisten kulttuurisuhteiden luomiseksi [...] 21.10. Hufvudstadsbladet ehdottaa pääkirjoituksessaan venäjän-kielen ottamista koulujen opetusohjelmistoon...Suomen kommunistinen puolue on rekisteröity [...] 31.10. Iltaradiossa odotettu uutinen: suojeluskuntajärjestö on lakkautettu. Siinäpä tieto, joka tulee vavahduttamaan koko Suomen [...]. (Paavolainen 1946, 579-589.)
\end{abstract}

Kanen teorian mukaan yhteisymmärrys on välttämättömyys kaikelle sosiaaliselle ja kulttuuriselle toiminnalle. Jotta moniääniset tahot (kuten esimerkiksi SKDL, SDP ja Maalaisliitto, jotka olivat johtavat hallituspuolueet Suomen ensimmäisessä sodanjälkeisessä hallituksessa) kykenevät toimimaan edes jonkinlaisessa yhteistyössä murrosaikana, on kulttuurisissa ja sosiaalisissa liikkeissä (jollaiseksi myös jälleenrakennus on ymmärrettävä) vaikuttavien moniäänisien osallistujien löydettävä jokin yhteinen 


\section{JälLEENRAKENTAMISEN NARRATIIVIT JA NIIDEN MUOTOUTUMINEN SUOMEN LEHDISTÖSSÄ 1944-1945}

perusta, jonka varassa toimia. Kanen mukaan yhteinen perusta on usein joustava, neuvottelun ja tulkinnan varaan syntynyt. Se valjastaa käyttöönsä muunneltuja tai mukautettuja kulttuurisia selitysmalleja ja rakenteellisia ehtoja (Kane 2000, 313). Hyvä esimerkki muunnellun ja mukautetun kulttuurin selitysmallin narratiivista, jossa rakenteiden ja muutoksen välttämättömyys korostuu, on L. Arvi P. Poijärven (kouluhallituksen pääjohtaja vuosina 1942-1945) kirjoitus "Tulevaisuus" Kotilieden ensimmäisessä rauhan ajan numerossa vuonna 1944. Poijärven mukaan rauhaan paluu voi onnistua vain jos

aivan jyrkästi käännämme selkämme vanhoille uskomuksillemme sellaisista asioista kuin yhteiskuntaryhmien väliset arvoasteet, vanhanaikaiset työsuhteet, maanomistusolot, yksityisomaisuus, puolue-elämä ym. ja suorastaan vallankumouksellisella ennakkoluulottomuudella lähdemme ratkomaan edessämme olevia valtavia probleemeja. Ellemme tähän pysty, emme myöskään voita vastassamme olevia vaikeuksia, vaan ne voittavat meidät ja taistelumme, joka kirvelevistä haavoistamme huolimatta on taannut meille paikan maailman suvereenisten kansojen joukossa, on osoittautuva turhaksi. (Kotiliesi 19/1944, 550.)

Historiallisessa selitysmallissa, jossa kulttuurin konstruktiivinen luonne on tutkimuksen keskiössä, kyky selittää ja analysoida merkityksien konstruointia on välttämättömyys yhteiskuntien monimuotoisen toiminnan ymmärtämiseksi. Jotta voimme paremmin ymmärtää, miten "historiallisesta tapahtumasta", kuten jälleenrakennuksesta, on konstruoitu idyllinen ja homogeeninen käsite, on välttämätöntä palata prosessin alkulähteille eli jälleenrakennusaikaan ja tarkastella historiallisessa kontekstissa, miten jälleenrakennuksen merkityksiä on konstruoitu. Vain siten voimme ymmärtää, miksi, kuten yllä mainitut 2000-luvun esimerkit osoittavat, jälleenrakennuksesta on muodostunut käsite, jolla implikoidaan kansan parhaita ominaisuuksia, joka on aukoton ja yhtenäinen mutta ei välttämättä vastaa aikalaisten "todellisuutta" tai kokemuksia.

\section{NARRATIIVISET SYMBOLIT}

Narratiivinen tutkimus, narratiiviset juonirakenteet ja niiden symbolisuus ovat monille historioitsijoille yhä punainen vaate. Monet tutkijat ovat vetäneet rajan tekstuaalisuuden ja kontekstuaalisuuden välille pohtimatta, miten ne lävistävät toisensa. Esimerkiksi Juhani Myllyn mukaan Hayden "Whiten jälkeen valinta tekstuaalisuuden ja kontekstuaalisuuden välillä on luonteeltaan paradigmaattinen ja väistämätön." (Mylly 2002, 20.) Kaarina Koski on kirjoittanut, että Jorma Kalelan mukaan "tutkimustyön kulku ja työn tulosten raportoinnin haasteet viittaavat 'johonkin muuhun kuin tarinointiin"” (Koski 2007, 7-8). Toisaalta on huomautettava, että narratiivi ei ole sama asia kuin tarina - tai kertomus. Kertomuksesta ja tarinasta voi kysyä, onko se totta. Narratiivista tätä kysymystä ei voi esittää (ks. Kalela 1993, 175). Yhteistä sekä narratiiville 


\section{Antero Holmila}

että kertomukselle ja tarinalle on se, että symbolisuus liittyy niihin kiinteästi. Symbolit toimivat usein ilmaisun välineenä. (Pekonen 1991, 27.) Paul Ricoeur on muistuttanut, että narratiivin avulla tapahtumat symboloidaan. Ilman symbolisuutta tapahtumien historiallinen arvo on vaikea paikantaa. (Ricoeur 1978, 98; ks. myös White 1990, 53.) Esimerkiksi "talvisodan henki" symboloi talvisodan aikaista mentaalimaisemaa, mutta se, mitä talvisodan henki "oikeasti" merkitsee tai tarkoittaa, on ymmärrettävissä vain kielellisen ilmaisun kautta. Ei ole olemassa lähdeaineistoa, joka sinällään kertoisi talvisodan hengestä. Miten siis asioiden, ilmiöiden ja tapahtumien merkityksiä voidaan tutkia?

Anne Kanen mukaan paras tapa löytää merkityksiä on tutkia kulttuurisien rakenteiden "aktiivisia" komponentteja, nimittäin narratiiveja (tai kertomuksia). Kuten Ricoeur, myös Kane argumentoi, että narratiivit käyttävät ymmärrystä helpottavia symbolisia koodeja hyväkseen merkityksen luomisessa. Yksilöt, ryhmät ja yhteiskunnat taas tukeutuvat näihin narratiivisiin symboleihin luodessaan omaa maailmankuvaansa (Pekonen 1991; Eco 1984). Lisäksi on huomattava, että narratiivit ovat loogisesti järjesteltyjä ja niiden logiikan määrää "juoni”, jossa juonen käänteiden avulla tietyt tapahtumat, toimijat ja rakenteet sijoitetaan järkiperäiseksi kokonaisuudeksi. Näin ollen narratiivi on osa ihmisen kognitiivista välineistöä, jolla hän jäsentää maailmaa. (Mink 1987, 133.)

Narratiivin kognitiivisen ulottuvuuden lisäksi on Kanen tapaan huomioitava, että niillä on myös kyky luoda voimakkaita kollektiivisia emootioita, kuten ylpeyttä, häpeää, vihaa ja lojaalisuutta, koska ne ovat pyhien symbolien järjestelemiä ja niihin ankkuroituja (Kane 2000, 316). Tällaisia symbolien järjestelemiä narratiiveja on esimerkiksi isänmaa, kansa tai sankaruus. Nämä käsitteet olivat tärkeällä paikalla jälleenrakennusajan maailmanselityksessä: niiden avulla usein järjesteltiin jälleenrakennusajan hallitsevat narratiivit, jotka korostivat "selviytymistä", "uhrautumista" ja "itsehillintää". Lisäksi niillä merkityksellistettiin sodasta selviäminen ja jälleenrakennus niin dominoivasti, että 2000-luvulla näiden konstruktioiden metanarratiivina voidaan puhua jälleenrakennuksen yhtenäiskulttuurista. Viimeisenä huomiona narratiivin luonteesta, joka myös jäljempänä käy esille, on se, että niiden loppupäätelmät ovat usein epäselviä. Kerronta-ajankohtana tapahtumat ovat vielä käynnissä ja äärimmäinen lopputulos riippuu vastaanottajan toimista (Kane 2000, 316). Margaret Somersin mukaan ihmisten toiminta - tai toimettomuus - riippuu osaltaan siitä, miten he paikallistavat itsensä narratiiveissa (Somers 1994, 618). Näin ollen voi esimerkiksi olettaa, että naisväestön tapa paikallistaa itsensä " uhrautumisen" narratiivissa, jossa naisia kehotettiin luovuttamaan työpaikkansa kotiutuvien miesten hyväksi, vaikutti sen lopputulokseen.

\section{SODAN VAAROISTA VAARAN VUOSIIN. HistoriallinEN KONTEKSTI VUOSINA 1944-1945}

Sodanjälkeistä aikaa vuodesta 1944 vuoden 1948 eduskuntavaaleihin on yleisesti nimitetty "vaaran vuosiksi", joskin historioitsijoiden mielipiteet eroavat siitä, kuinka 


\section{JälLEENRAKENTAMISEN NARRATIIVIT JA NIIDEN MUOTOUTUMINEN SUOMEN LEHDISTÖSSÄ 1944-1945}

pitkälle tätä nimitystä on mahdollista käyttää. Erityisesti Suomen ulkopolitiikkaa koskevissa kysymyksissä "vaaran vuosista" on esitetty kriittisiä arvioita (esim. Rautkallio 1990; Seppinen 2008). Kansakunnan sielunmaisemaan vaikuttivat kuitenkin enemmän kuvitellut pelot, kuten neuvostomiehityksen mahdollisuus ja kommunistien vallankaappaus, kuin esimerkiksi se, miten pragmaattisesti Stalin todellisuudessa suhtautui Suomen tapaukseen - sitähän eivät suomalaiset silloin tienneet. Lauri Hyvämäen klassikoksi noussut tulkinta "vaaran vuosista" jakautuu kahteen jaksoon: "Aallonpohjassa" 1944-1946 ja "Vastavaikutus" 1946-1948. (Hyvämäki 1954, 192). Tämä artikkeli ajoittuu ensimmäiseen periodiin, koska juuri silloisessa "aallonpohjassa" rakennettiin jälleenrakennustarinan peruselementit, jotka ovat olleet sen jälkeen varsin muuttumattomia.

Suomen rauhanneuvotteluvaltuuskunta allekirjoitti Moskovassa välirauhan 19. syyskuuta 1944. Luonteenomaista välirauhaa seuranneille kuukausille oli sen vaatimien muutosten toteuttaminen erityisesti Suomen sisäpolitiikassa. Ensinnä armeija oli demobilisoitava lyhyessä ajassa, mutta samalla oli saksalaiset ajettava pois Suomen alueelta. Vajaa viikko välirauhan solmimisen jälkeen Liittoutuneiden Valvontakomissio saapui Suomeen. Tällöin saapuneet virkamiehet olivat kaikki venäläisiä, ja heidän ohjeensa demobilisaation ja saksalaisten maastakarkottamisen suhteen olivat epäselvät. Lisäksi aallonpohjassa oli ratkaistava evakkojen asuttaminen ja asuntokysymys yleisimminkin, rintamamiesten työllistäminen, sotakorvausmaksujen aloittaminen ja monta muuta polttavaa kysymystä. Toukokuussa 1945 asekätkentäjuttu nousi julkisuuteen ja saman vuoden jälkimmäisellä puoliskolla alkoi taistelu sotasyyllisyyskysymyksestä, joka jatkui talveen 1946. Se, että sotasyyllisyyskysymyksessä kansa koki tulleensa väkipakolla alistetuksi epäoikeudenmukaisuuteen lain edessä, oli maan valtaväestölle kipeä asia. Lisäksi on muistettava, että kommunistin (Yrjö Leino) toimiminen sisäministerinä Itä-Euroopan mallin mukaan ei myöskään ollut monien mielestä lupaava enne.

Välirauhaa seuranneina päivinä maan - ja maailman - lehdistö kommentoi rauhaa, sen ehtoja ja Suomen tulevaisuuden näkymiä. Samoin tekivät myös yksityiset ihmiset. Paasikivi kirjoitti päiväkirjaansa 20. syyskuuta "Hirmuinen sopimus! ", jatkaen seuraavana päivänä: "Tänään lehdissä välirauhansopimuksen teksti. Hirmuinen! Hirmuinen! [...] Kysymys on, voiko Suomen kansa enää tämän jälkeen kansana elää’. (Blomstedt \& Klinge 1985, 32.) Tosin Paasikivi itse avustajiensa kanssa muokkasi 1950-luvulla päivittäisiä merkintöjänsä. Hän halusi jättää jälkimaailmalle kuvan valtiomiehestä, joka seurasi maailmaa rationaalisesti ja laaja-alaisesti tavalla, jossa yhdistyvät historian filosofinen pohdiskelu ja valtiollinen kylmäpäisyys (ks. lähemmin Paakkunainen 1986,144-154). Lauri Jäntti puolestaan arvioi tilannetta 20.9. päivätyssä kirjeessään vaimolleen seuraavin sanakääntein:

Vakavina kuuntelimme iltauutisia eilen [19.9.]. Kyllä ne Bornin sanat (raubanehdot) veivät mielen matalaksi [...] Huomaat minun monen muun lailla kerrankin olevan pessimistinen. Ajattelevalle ihmiselle on tulevaisuus synkkä. (Jäntti 1983, 306-307.) 


\section{Antero Holmila}

Uusimmassa historiankirjoituksessa käytetäänkin termiä "rauhan kriisi", jolla kuvataan näitä yllä mainittuja tuntoja. "Vaaran vuosien" ajatuksesta, jonka mukaan maa oli jatkuvan miehitysuhan alla rauhasta huolimatta, on keskustelu kääntynyt "rauhan kriisiin", joka heijastaa paremmin aikalaisten tunnetiloja kuin ulkopolitiikan kiemuroita. (ks. esim. Karonen \& Tarjamo 2006, 18-19.) Näissä myrskyissä Suomen lehdistö loi pohjan jälleenrakennuksen merkitykselle.

\section{VÄLIRAUHA JA SELVIYTYMISEN/YHTEISTYÖN NARRATIIVI}

Jos yllämainituissa yksityisissä arvioissa korostuu pessimistinen mieliala, muotoili Suomen lehdistö asian - Valtion tiedotuslaitoksen painottamana - erilaisessa sävyssä. Kaikista voimakkaimmin sodan ja rauhan rajalla nousee esille "selviytymisen narratiivi". Helsingin Sanomien pääkirjoituksen viimeinen kappale heti välirauhan tultua on kuvaava:

Lohdutuksena ja rohkaisijana tässä kohtalon ankarassa vaiheessa on se, että Suomen kansa on usein ennenkin joutunut kokemaan kovia koettelemuksia ja kyennyt niistä selviytymään. Nïn tulee tapabtumaan tälläkin kertaa, kun vain säilytämme järk.kymättömän tulevaisundenuskomme ja elämisen tahtomme. Keskinäisessä luottamuksessa on meidän nyt alaltaan pienentyneessä ja köyhtyneessä isänmaassamme ponnisteltava valoisampiin aikoihin. (HS 20.9.1944, 4. Kursivointi lisätty.)

Karjalan Sanomat kirjoitti selviytymisestä hyvin samaan tapaan kuin Helsingin Sanomat.

Millaiseksi taakkamme muodostuukin on meidän kuitenkin se kyettävä kantamaan. Suomen kansan elämässä eivät suuret vaikeudet ja koettelemukset esiinny ensimmäistä kertaa. Monesti on niitä vuosisatojen aikana ollut, mutta silti on elämä jatkunut. (Karjalan Sanomat 20.9.1944, 2.)

Tämä viesti päti erityisen voimakkaasti evakoille, jollaiseksi myös Karjalan Sanomat voidaan lukea. Kalevan pääkirjoitus puolestaan toivoi erityisesti "hallitusmiehillemme voimia kestää nyt saamamme iskut ja toimia niidenkin jälkeen siten, että voimme elää erityisenä kansana, joka ei sorru vaikeuksissa, niinkuin [sic] eivät esi-isämmekään tehneet silloin kun niiden osana oli kokea idän suurmyrskyjä" (Kaleva 20.9.1944, 2). Suomen kansa ja isänmaa ovat tässä kerronnassa tärkeässä asemassa, koska voidaan olettaa, että näissä ilmauksissa on symbolisella tasolla erilaisille lukijoille erilaisia korostuksia ja tunnelatauksia. Vaikka lukijat määrittivät ne kukin itsessään, niillä samalla kuitenkin tarkoitettiin myös yhteisiä ja yhtäläiseksi koettuja asioita. Näin ollen kokemuksiltaan ja taustoiltaan hyvin erilaiset tahot pystyivät löytämään yhteisiä ja yhdistäviä kertomuksia menneisyydestä. Kuten Paul Connerton $(1989,5,70)$ on 


\section{JälLEENRAKENTAMISEN NARRATIIVIT JA NIIDEN MUOTOUTUMINEN SUOMEN LEHDISTÖSSÄ 1944-1945}

kirjoittanut, yhdistävillä viesteillä voidaan "ymmärtää menneisyyttä ikään kuin kollektiivisena oma-elämäkertana."

Professori Aulis J. Alanen antoi Suomen Kuvalehdessä konkreettisempia esimerkkejä Suomen kollektiivisesta oma-elämäkerrasta ja siitä, miten myös ennen kansa oli voittanut rauhan haasteet. Hänen mukaansa "vastaus" siihen, mitä hyötyä hävitystä taistelusta on ollut, löytyi menneisyydestä:

Ei sielläkään kukaan esi-isistämme vaatinut perusteluita, kun oli kysymys maamme ja kansamme olemassaolosta. Taisteltiin hammasta purren, ja taistelun jälkeen eloonjääneet nostivat tuhkasta rakennukset ja aloittivat kuten Saariiärven Paavo uudestaan. Kuinka monta kertaa onkaan Suomen kansan ollut alettava alusta. (Suomen Kuvalehti 40/1944, 1136.)

Kansallisromanttisessa hengessä Suomen kansa siis nivoutui Paavoon symboloiden ihanteellista agraari-Suomea, jossa työ, usko Jumalaan ja lähimmäisenrakkaus olivat keskeisiä ja lukijoiden tunnistamia symbolisia kulttuurikoodeja. Kun nämä symboliset koodit liitettiin Paavon avulla vallitsevan tilanteen tulkintaan, myös jälleenrakennuksesta tehtiin osa kansanperinnettä "Paavon hengessä". Lisäksi yllä lainatussa tekstissä historian professorin auktoriteetti on esillä itsestäänselvyytenä: Alasen tekstin mukaan oli turha ajatella liikaa ja etsiä vastauksia siihen, mitä hyötyä sodasta oli ollut. Liika ajattelu ei Suomen loppuvuoden 1944 tilanteessa auttanut. Oli parempi vain toimia turhia kyselemättä, kuten Paavo, ja aloittaa uudestaan.

Toisaalta Alanen lohdutteli lukijoitaan sillä, että suhteutettuna vuosien 1939-1944 sotiin, 30-vuotinen sota vastasi yli puolen miljoonan suomalaisen tappiota. Vieläkin kovempia koettelemuksia oli edessä: "ISOVIHA onkin kansamme historian suurinta kärsimysaikaa, mutta myöskin suurimman sitkeyden ja sankarillisuuden aikaa ennen nykysotia." Tällöin henkilötappiot vastasivat yli miljoonaa suhteutettuna maan väkilukuun. Kuten kautta historian, Suomen selviytymisessä sodasta rauhaan vuonna 1944 oli yksi tekijä ylitse muiden: "aseveljeyden siteet, jotka ovet vieneet maamme kaikki kansankerrokset yhteen yrittäessämme voittaa yhteisiä suuria vaikeuksiamme. Sukuun tai säätyyn katsomatta on kansamme kamppaillut olemassaolonsa puolesta, yhdessä taistellut, yhdessä kärsinyt, yhdessä köyhtynyt." (Suomen Kuvalehti 40/1944, 1136-1137.) Kärsimys (symbolisesti myös sodanjälkeinen) kävi yhteen sankarillisuuden ja sitkeyden kanssa. Tähän kulttuurisesti konstruoituun sanomaan oli helppo yhtyä.

Näissä historian todistuksissa on erityisen huomionarvoista sekä niiden kansanomaisuus (esimerkiksi Saarijärven Paavon symbolinen merkitys) että riittävän pitkä välimatka kirjoitushetkeen. (vrt. Alasuutari 1996, 186.) Siinä, missä sotavuosina historian jatkuvuutta todistettiin suomalaisen taistelun iankaikkisuudella itää vastaan Vänrikeki Stoolin ja Maamme-kirjan hengessä, sopi vähemmän sotaisa Paavo jälleenrakentajaksi. Toisekseen mitä kauempaa historian hämärästä näitä kollektiivisesti yhdistäviä symboleita voitiin hakea, sitä pienempi oli mahdollisuus, että lukija tulkitsisi tekstiä vastakarvaan havaiten niissä kansaa eriyttäviä tekijöitä. Historiallisesta kontekstista käsin on mahdollista ajatella, että Isoviha oli kärsimysaikaa erityisesti Pohjanmaalla, ei niinkään Viipurissa. Lisäksi on mahdollista esittää, että Isonviha eriytti suomalaisia, 


\section{Antero Holmila}

koska etenkin rahvaan kärsiessä Isonvihan aikana suuri määrä porvaristoa ja papistoa pakeni Ruotsiin. Ymmärrettävästi historian esimerkit eivät kertoneet, miten Suomi selvisi ja palasi rauhaan vuoden 1918 sisällissodasta. Tämä myös osaltaan liittyy narratiivien epäselviin loppupäätelmiin; narratiivit muodostuvat sellaisiksi kuin lukijat ne omiin tarpeisiinsa rakentavat. Lisäksi on huomioitava, että yhtenäiskulttuurin käsite on konstruoitu nimenomaan symbolisella tasolla, jolloin mytologisesta historiasta tulee ikään kuin totta. Vuonna 1944 kansan esimerkillistä yhtenäisyyttä haettiin Saarijärven Paavon symbolismista.

\section{DEMOBILISAATIO JA UHRAUTUMISEN/VELVOLLISUUDEN TÄYTTÄMISEN NARRATIIVI}

Uhrautumisen/velvollisuuden täyttämisen kerronta vaikutti erityisen voimakkaasti kahdella tasolla. Ensimmäinen, ulkoinen taso, tarkoitti välirauhansopimuksen velvoitteiden täyttämistä, joka vaati uhrauksia koko kansalta. Helsingin Sanomat kirjoitti pääkirjoituksessaan 24. syyskuuta, että "meidän tehtävämme on nyt ryhtyä toteuttamaan välirauhansopimuksen mukaisia velvoitteitamme" ja että Neuvostoliiton painostuksen alla "vain märä̈tietoisella johdolla voidaan vaikeassa tilanteessa pelastaa se, mikä on pelastettava, jos tahdotaan torjua vielä suurempia vaaroja." (HS 24.9.1944, 6.)

Uhrautumisen narratiivin toinen taso oli puolestaan kiinteästi sidoksissa sodanjälkeisen sukupuolijärjestelmän koodaukseen, jossa ajatus uhrautumisesta ja velvollisuuden täyttämisestä kohdistui erityisesti maan naisväestöön. Ennen kaikkea heidän velvollisuutensa oli, ainakin dominoivan lehdistön mielipiteen mukaan, luovuttaa työpaikkansa kotiutuville rintamamiehille, jotka olivat jo rintamalla uhrautuneet aivan tarpeeksi.

Tyyne Leivo-Larsson (SDP:n kansanedustaja vuosina 1948-1958 ja 1966-1970) kirjoitti vahvalla auktoriteetilla "Nainen työmarkkinoilla sodan jälkeen" otsikoidun artikkelin, joka ilmestyi Kotiliesi-lehdessä: "Nyt ei ole houkutuksin enempää kuin velvoituksinkaan pyrittävä lisäämään naisten lukua työmarkkinoilla, vaan päinvastoin on kehotettava naisia jättämään vapaaehtoisesti työpaikkansa sodasta palaaville miehille.” Larsson kuitenkin tunnusti, että kysymys naisten vetäytymisestä pois työmarkkinoilta ei olisi helposti ratkaistavissa, sillä naisten joukossa oli myös paljon perheen elättämisestä vastuussa olevia naisia, erityisesti sotaleskiä ja sotainvalidien vaimoja. Naisten työvoimakysymyksen tyydyttävä ratkaisu kuitenkin vaati heiltä "suurta joustavuutta, omaa aktiivisuutta ja uhrivalmiuttakin". Larssonin lopettaa seuraavin sanakääntein: "Yhteiset vaikeudet on voitettava. Naiset eivät nytkään halua vetäytyä vastuusta, vaan ovat valmiit joustavasti mukautumaan uusiin oloihin, kunhan heille vain tunnustetaan oikeus työhön samalla tavalla kuin miehillekin." (Kotiliesi 21/1944, 614-615. Kursivointi lisätty.)

Leivo-Larssonin artikkeli on ristiriitainen, koska siinä toisaalta kehotetaan naisia vetäytymään vapaaehtoisesti työhön palaavien miesten tieltä, toisaalta naisten oikeus työhön miesten rinnalla on korostetusti esillä. Tällainen sisäinen ristiriitaisuus 
JÄLlLENRAKENTAMISEN NARRATIIVIT JA NIIDEN MUOTOUTUMINEN SUOMEN LEHDISTÖSSÄ 1944-1945

ei sinänsä ole kuitenkaan yllättävää, sillä on huomattava, että artikkelin juttutodellisuus liikkuu useilla tahoilla, puhutellen hyvinkin eri tavoin eri ikäryhmiin ja ammattikuntiin kuuluvia naisia. Työmääräyksin työmarkkinoille tulleiden naisten tuli "vetäytyä takaisin perheensä pariin tai entiseen, sodan aikana vähemmän tärkeänä pidettyyn työpaikkaan", kun nuorten (naisten) tulisi hakea "koulutettavien ja uudelleen sijoitettavien joukkoon". Yhdistävänä tekijänä, koskien kaikkia naisia ikään, työkokemukseen tai erikoisosaamiseen liittymättä, on kuitenkin vaatimus uhrauksista. Naisilta ja kotirintamalta vaadittiin uhrauksia, koska sodan seurannaisena jo ennestään maskuliinisessa sukupuolijärjestelmässä miehillä oli yksi auktoriteettinen etu lisää, joka oli ratkaisevammassa roolissa kuin naisten palkkatyö sotavuosina: "Tulirintamalta palaavat miehet ovat näinä sotavuosina saaneet kantaa raskaimman henkilökohtaisen vastuun maan kohtaloista ja antaa suurimman uhrin. Kotirintama tuntee ja tunnustaa tämän.” (HS 30.9.1944, 4.) Toisin sanoen naisten uhraukset palkkatyön osalta olivat pieniä verrattuna miesten antamiin sodan uhreihin. Siksi pienestä ei pitänyt valittaa.

Jos lehdistö vaati naisilta uhrivalmiutta työmarkkinoilla, myös kotiinpaluussa, erityisesti sodan runtelemien miesten mukauttamisessa siviilielämään, naisilta vaadittiin suuria uhrauksia. Se, miten ottaa sodasta palaava mies vastaan, askarrutti sekä sanoma- että aikakausilehdistöä. Asiaa pohti muiden muassa Suomen Kuvalehti ja Kotiliesi. Suurin ongelma koski kahden rintaman, koti- ja tulirintaman, menestyksellistä yhteensovittamista, sillä lehdistön kirjoitusten mukaan näiden kahden maailman valtava ero ymmärrettiin selkeästi.

Erityisesti kiinnitettiin huomiota nuorten miesten kotiinpaluuseen. Monet olivat lähteneet sotaan 18 tai 19 vuoden iässä ja viettäneet rintamapalveluksessa viisikin vuotta. Nämä miehet olivat hädin tuskin ehtineet irtautua "henkisesti vanhempiensa kodista, mutta eivät vielä [olleet] saaneet itsenäistä otetta rauhanaikaisesta elämästä ja olemisesta ennenkuin [sic] rintama tempasi heidät piiriinsä. Heille taisteluhautojen, kämppien, korsujen, komppanioiden ja töpinöiden tienoot olivat ainoata miehisen elämän muotoa.” (Suomen Kuvalehti 41/1944, 1178-1179.)

Samaan ongelmaan puuttui "isoäiti" Kotiliesi-lehden palstallaan otsikon "[m]iten otan hänet vastaan" alla. Hän kirjoitti miten "[h]e [sotaan kutsutut miehet] olivat nuorukaisia mennessään”, jatkaen:

nuorukaisia, joita koti valvoi askel askeleelta ja jotka olivat kodista riippuvaisia epäitsenäisiä, lapsellisia poikia. He ovat nyt käyneet raskasta sodan koulua. Jos kohta oppikoulu ehkä jäikin kesken, niin elämänkoulu on heitä niin kypsyttänyt, että he eivät enää voi olla epäitsenäisiä lapsia, joita vanhemmat kuten ennen joka askeleelta seuraavat. Mutta toisaalta he tarvitsevat kotia nyt enemmän kuin ennen, sillä heidän kotikasvatuksensa keskeytyi. (Kotiliesi 20/1944, 605.)

Vaikka äideiltä odotettiin paljon nuorten miesten kotouttamisessa, vielä enemmän vaadittiin aviovaimoilta (tosin paljon oli niitä, jotka olivat sekä äitejä että aviovaimoja). Isoäidin jo yllä mainitussa kirjoituksessa on pääpaino aviovaimojen ohjeistamisessa. 


\section{Antero Holmila}

Lähtökohtana on kuitenkin sodan miehille suoma maskuliininen auktoriteetti, joka ohjaa kaikkea muuta toimintaa:

kuinka suuri onkaan muutos nyt niissä miehissä, jotka kauan aikaa ovat olleet tavallaan kodin vaikutuksen ulkopuolella, aivan erilaisissa oloissa kuin kotona, kokien aavistamattomia järkytyksiä, mutta samalla myös kohottavaa yhteismieltä, altista, uhrautuvaa toveruutta, ja omistaen jakamattomasti elämänsä, työnsäj ja harrastuksensa vain yhdelle ainoalle päämäärälle, Suomen puolustukselle. (Kotiliesi 20/1944, 588.)

Kun miehinen auktoriteetti on näin absoluuttisesti konstruoitu, jäljelle jää kysymys, miten aviovaimon on toimittava. Isoäidin mukaan "ei ole meillä suomalaisilla nyt aikaa eikä tilaisuutta itsekkäisiin oman onnen pyyteisiin". Toisin sanoen suomalaisten, erityisesti naisten, velvollisuus oli epäitsekäs uhrautuminen. Myös silloin kun kotiin tulee mies,
joka on unohtanut entisen rakkautensa [aviovaimon] ja luulee löytäneensä kestävämmän onnen jonkun työtoverinsa tai satunnaisesti tapaamansa henkilön rinnalla...Olen saanut monta kirjettä vaimoilta, joiden miehet ovat hetkeksi unohtaneet kotinsa ja velvollisuntensa sitä kohtaan. Mutta he olivat urhoollisia naisia, jotka eivät masentuneet. He koettivat ymmärtää niitä kiusauksia, joissa mies oli kaukana kodistaan, ja antaessaan kaiken anteeksi he saavuttivat rakkauden aivan uudella tavalla. (Kotiliesi 20/1944, 588.)

Kotiliedessä oleva palsta "Isoäidin kirjeenvaihto" todellakin oli täynnä juuri tämänkaltaisia vastauksia. Yhteistä niille kaikille oli se sama perusvire, jonka mukaan naisten velvollisuus oli uhrautua miesten puolesta. Esimerkiksi mainittakoon Isoäidin vastaus "Paljon kärsineelle":

Paljon tämä sota-aika vaikeuttaa kotielämää ja särkee sen onnea. Mutta jos mies ei aina jaksakaan pysyä uskollisena, niin sitä tärkeämpää on, että äiti on sellainen, että lapset voivat häntä kunnioittaa [...] Eroa et saa ajatellakaan [...] Saat nähdä, että mitä syvemmin opit antamaan anteeksi, mitä enemmän unohdat itsesi ja ajattelet lastesi onnea, sitä suuremman henkilökohtaisen onnen sinä itsekin saavutat. (Kotiliesi 12/1944, 376. Vastaus nimimerkille "Paljon kärsinyt".)

Monet todellakin elivät tällaisten ohjeistusten mukaan, mutta se, minkälainen henkinen perintö on rauhaan paluun aiheuttamasta perhekriisistä välittynyt sukupolvelta toiselle, on toistaiseksi epäselvää. Tosin historiankirjoitus on lisääntyvässä määrin alkanut kiinnittää huomiota myös tällaisiin sodan pitkäkestoisiin ilmiöihin (ks. Kinnunen \& Kivimäki 2006; Karonen \& Tarjamo 2006). Artikkelini tulosten perusteella voi ainakin sanoa, että yllä esitetty normatiivinen ja maskuliinista hegemoniaa yllä pitävä narratiivi 


\section{JälLEENRAKENTAMISEN NARRATIIVIT JA NIIDEN MUOTOUTUMINEN SUOMEN LEHDISTÖSSÄ 1944-1945}

auttoi yhtenäiskulttuurin luomisprosessissa. Samaan tapaan kirjoitti nimimerkki I. K., että miehen tullessa sodasta on "Sinun [naisen] vuorosi kestää. Koeta joka päivä viekoitella perheen pää onnellisena hymyilemään." (Kotiliesi 9/1945, 277.)

Kotiliesi julkaisi vuoden 1944 lopulla myös miesnäkökulman kotiin paluuseen - täysin sopusoinnussa lehden yleisen linjan kanssa. Nimimerkki "Rintamalta palaava mies" kertoi rintamamiesten odotuksista ja peloista. "Mitä me sitten kodeilta odotamme?" hän kysyi.

Ensiksi tietysti, että meidät otetaan avosylin vastaan, olkoonpa koti millainen tahansa. Emme me myöskään ole mitään sankareita joita tarvitsisi palvoa tai palvella, olemme tottuneet kenties tulemaan toimeen kotonakin pienemmin vaatimuksin kuin ennen. Mutta vaikka viestejä lienee kantautunut siitäkin kuinka hyviä räiskäleenpaistajia tai kastikkeenvalmistajia olemme korsussa olleet ja kuinka monta kertaa olemme oman pyykkimme pesseet, niin älköön meiltä myöskään innostuttako vaatimaan kaikkea mahdollista. (Kotiliesi 21/1944, 621.)

Tämän tulkinnan mukaan miehet pystyisivät sopeutumaan varsin hyvin kotioloihin, kunhan se kävi - ainakin ulkoisesti - miesten ehdoilla. Todellisuudessa kotiinpaluu oli usein vaikea, joskin siksi ounasteltu, sillä sodan vielä kestäessä "miehet olivat ehtineet luomaan haavekuvia siitä, mitä kaikkea sitten tehtäisiin, kun suuri päivä vihdoin koittaisi” (Janatuinen 2005, 131). Kotiinpaluun ja siviilielämään sopeutumisen vaikeuksista osaltaan tietenkin kertovat nopeassa tahdissa kasvaneet avioerojen määrät, jotka myös ilmentävät kansakunnan henkistä epävakautta, johon puolestaan vaikutti kyvyttömyys purkaa sodan aiheuttamia traumoja.

Jenni Janatuinen (nykyisin Kirves) on analysoinut Kalle Päätalon tapaa purkaa - tai paremminkin olla purkamatta - sodan traumaattisia muistoja lähes järjettömään työntekoon. Kirveen mukaan Päätalo hukutti sotatraumansa, koti-ikävänsä, ongelmallisen avioliittonsa ja epävarmat tulevaisuuden näkymät urakkatöihin, jotka vain kiihdyttivät negatiivista tunneympäristöä. Työ lisäsi väsyneisyyttä, ja "[v]äsyneenä ei pystytty kontrolloimaan omaa käyttäytymistä ja oltiin äreitä [...] Ne, jotka pääsivät työhön kiinni, antautuivat siihen heikkopäisesti. Oma työ oli ainoa asia, johon saattoi luottaa toisen maailmansodan hajotettua ihmisten perusluottamuksen maailmaan ja toisiin ihmisiin.” (Janatuinen 2005, 146-147.) Jälkiviisaasti voi todeta, että myös lehdistö omalla holhoavalla asenteellaan vaikutti tällaisen normatiivisen työ-unohdusviitekehyksen luomiseen. Savon Sanomat kirjoitti pääkirjoituksessaan rauhaan paluusta, että rauhaan siirtyminen oli talouden alalla "vaikea prosessi", jatkaen:

Mutta vielä ankarampi on se siveellinen murros, joka sodasta palaavien ja heidän kotiensa on läpikäytävä. Mitä lyhyemmäksi ja tasaisemmaksi tämä siirtymävaihe saadaan, sitä parempi [...] Työ on parasta mielialan hoitoa, ja sen parissa raskaat kokemukset tasaantuvat ja haavat arpeutuvat. (Savon Sanomat 20.9.1944.) 


\section{Antero Holmila}

Savon Sanomat siis suorastaan kehotti tekemään työtä ja unohtamaan. Monet, kuten Päätalo, toimivat juuri niin. Toisaalta on kuitenkin muistettava, että tilanne Suomessa oli ristiriitainen: vaikka työnteolla oli usein yllä kuvattu negatiivinen funktio, oli silti toisaalta selvää, että vain työtä tekemällä voisi kansakunta nousta jälleen jaloilleen. Silvo Hietasen mukaan maa kärsi "vaaran vuosina" myös ylityöllisyydestä. "Työn evankeliumi veti mukaansa ja koulutti rauhanajan tositoimiin myös sodasta palanneet ammattitaidottomat nuoret miehet." (Hietanen 1992, 209.) On hyvin todennäköistä, että työn evankeliumi ja unohtamisen painottaminen kulkivat käsi kädessä.

Selviytymisen ja uhrautumisen kerrontojen lisäksi on vielä kolmas taho, joka on osittain limittäinen edellä esitettyjen narratiivien kanssa. Nimittäin molemmat, selviytyminen ja uhrautuminen, vaativat kansalta kollektiivista itsehillintää. Sitä tarvittiin juuri siksi, että kansakunta koki sodan paineen purkautumisen vapauttavana, mutta samalla vastuu sodan seurauksista selviämisestä jakautui kaikille yhteiskuntaryhmille ja molemmille sukupuolille.

\section{ITSEHILLINNÄN NARRATIIVI}

Lehdistöhistoriallisessa tutkimuksessa itsehillintää ei ole toistaiseksi käsitelty sosiaalipsykologisena prosessina. Sen sijaan itsehillinnän institutionaalinen muoto, itsesensuuri, on saanut paljon huomiota osakseen (ks. esimerkiksi Salminen 1979; Perko 1988; Uskali 2003). Lehdistö oli kuitenkin myös voimakkaasti tukemassa valtion linjaa, joka korosti itsehillinnän tärkeyttä rauhaanpaluuta ohjaavana tekijänä. Sisäministeri Kaarlo Hillilän 20. syyskuuta pitämä radiopuhe, joka myös näyttävästi julkaistiin seuraavana päivänä lehdistön palstoilla, ei jättänyt epäilystäkään hallituksen - ja myös lehdistön - linjasta. Helsingin Sanomat otsikoi puheen "Ehdoton velvollisuus säilyttää itsekuri”, ja sen mukaan "jokaisen kansalaisen on itsekurin solmuruoskalla ruoskittava itseään ja pidettävä huoli siitä, että hänen kohdallaan kuri ja järjestys säilyvät. Se on menestyksellisen eteenpäin pääsyn ensimmäinen edellytys.” (HS 21.9.1944, 2.) Samana päivänä, kun Hillillä puhui radiossa, oli Kansan Työ jo esittänyt oman arvionsa itsehillinnän tärkeydestä:

Viimeisten vuosien aikana on jo useammin kuin kerran suurten ratkaisujen hetkinä jouduttu vetoamaan kansamme yksimielisyyteen. Nyt yksimielisyyden säilyttäminen on tärkeämpää kuin milloinkaan ennen. Maan kaikkien kansalaisten on tinkimättä asetuttava sen ratkaisun taakse, jonka eduskunta ja hallitus ovat jo tehneet. (20.9.1944, 2.)

Vaatimus oli nimenomaan suunnattu väestön äärilaidoille, sekä oikealle että vasemmalle, koska näiden oletettiin olevan hallitukselle vähiten myötämielisiä. (Vrt. esim. Alasuutari 1996, 76, 97-98, 100, 107.)

Myös Helsingin Sanomien pakinoitsija "Eero" (Lassi Hiekkala) peräänkuulutti "Malttia ja tervettä järkeä". "Eeron" mukaan ei auttanut muu kuin "ottaa asiat sel- 
laisina kuin ne ovat". Ajopuuteoriaa ounastellen "Eero" puhui lukijoilleen tavalla, joka kiisti suomalaisilta oman aktiivisen osan ulkopolitiikan hoidossa: "Me olemme joutuneet olemaan nappulana suurten pelissä, jossa itsellämme ei ole ollut voimia eikä mahdollisuuksia läheskään aina tehdä niinkuin olisimme tahtoneet ja niinkuin oman maan ja kansan etu olisi vaatinut." Vaikka kansalaisten mielestä Suomi olisikin kokenut vääryyttä, oli "Eeron" mukaan kuitenkin nöyrästi - siis itsehillintää vaalien - tunnustettava valtiollisen elämän realiteetit. Ne olivat nyt uudella lähtöviivalla, johon "meidät on peruutettu viisastuneina, reippain ja vakavin mielin tekemään uutta taivalta valoisampaa tulevaisuutta kohti". (HS 28.9.1944, 3.)

Itsehillinnästä kirjoitti myös Kotiliesi. Isoäidin artikkeli "Itsehillintää" vuoden 1944 juhannusnumerossa heijastelee vielä niitä tuntoja, jotka vallitsivat Suomessa Kannaksen suurhyökkäyksen aikaan. Kirjoitus on kuitenkin tärkeä, koska siinä vedottiin juuri niihin teemoihin, joiden avulla sodan loputtua jälleenrakennettiin kansakunnan moraalia. Toisin sanoen tällaisen retoriikan näkökulmasta sodalla ja sodanjälkeisellä selviytymistaistelulla ei ollut huomattavaa eroa.

Isoäidin mukaan "kotirintamalaisilla" oli kaksi tapaa kantaa kortensa kekoon Suomen hyväksi. Ensinnä heidän tuli hoitaa työnsä "pelloilla ja vainioilla, tehtaissa ja kodeissa [...] kymmenkertaisella innolla". Toisekseen, kuten isoäiti kertoi, "[t]ulin aivan äskettäin huomioimaan erään seikan, joka on meidän tapamme lujittaa rintamaamme, ja se on itsehillintä’. (Kotiliesi 14-15/1944, 422.) Itsehillinnän puutteesta löytyi myös varoittava historiallinen esimerkki: "Tiedämme kaikki, että ensimmäisen maailmansodan ratkaisussa ei Saksan armeijaa koskaan voitettu, mutta kotirintama ei kestänyt, ja siksi lopulta armeijankin täytyi jättää taistelunsa kesken... Näin ei saa käydä meillä." Lisäesimerkiksi Isoäiti kertoi tapauksen, jossa myöhemmin Ruotsiin muuttanut "oppinut herra" oli ollut sitä mieltä, että "samahan se on, mitä me teemme, kun tämä sota kerran loppuu, ei meidän maastamme kuitenkaan ole mitään jäljellä!” Isoäidin mielestä " $[t]$ ällainen itsehillinnän puute on rikollista ja se juuri palvelee vihollisemme tarkoituksia." Sen sijaan, kuten Isoäiti opasti, "[m]eidän pitäisi löytää se asenne, että olisimme onnellisia siitä, että meilläkin on jotakin annettavaa isänmaalle." (Kotiliesi 14-15/1944, 422.) Tässä tekstissä on huomion arvoista, että itsehillinnän puutteesta kärsi nimenomaan oppinut herra, joka sittemmin muutti Ruotsiin. Tällaiseen hahmoon oli lukijoiden lähes mahdotonta samaistua, kun vielä muistetaan kirjoituksen alkuosio, jossa suomalaisen sotaponnistuksen luonne tiivistyy lauseeseen "pelloilla ja vainioilla, tehtaissa ja kodeissa". Tämä "oppinut herra" oli siis kaikkea muuta kuin "suomalainen". Hänen "epä-suomalaisuutensa", siis sen, että hänellä ei ollut mitään annettavaa isänmaalle, kruunasi Ruotsiin muutto. Vastaavanlaisia kansalaisia, teksti implikoi, ei Suomi tarvinnut.

Kouluneuvos ja kasvatusopin erikoisasiantuntija Aino Voipio (1) puolestaan opasti lukijoitaan maaliskuussa 1945 vaalimaan itsehillintää niin yksityis- kuin julkisessa elämässä. Heijastellen rauhaan paluun aiheuttamaa ulko- ja sisäpoliittista suunnanmuutosta ja juuri päättynyttä (21.2.1944) sotasyyllisyysoikeudenkäyntiä Voipio vei itsehillinnän korostamisen julkisessa elämässä aina valtioiden välisten suhteiden tasolle tavalla, jolla yksityisen ihmisen ja valtion toimintaa oli lähes mahdoton erottaa toisistaan: 


\section{Antero Holmila}

Tuota terveellistä itsehillintää tarvitaan aina, mutta erikoisesti silloin, kun yksityistä ihmistä, kotia tai kansaa vaikeat koettelemukset kohtaavat, jolloin pienikin harkitsematon sana tai teko voi johtaa arvaamattoman raskaisiin seurauksiin. Itsehillintään kuuluu monenlaista itsensä voittamista.

Itsensä hillitsevä ihminen ei erehdy kiivastuksissaan lausumaan syytöstä, jonka oikeudenmukaisuudesta hän itse on vakuuttunut, jos hän huomaa, että ne, joita hän aikoi syyttää, eivät omalta kehitystasoltaan asioita arvostellessaan pysty käsittämään olevansa väärässä, vaan ärtyvät siitä entistä enemmänkin vahinkoa aikaansaamaan.

Kiittäkäämme Jumalaa siitä, että kansallamme sen vaikeimpina koettelemusten hetkinä on ollut suuria miehiä ja jaloja naisia, joiden isänmaanrakkaus on ollut niin syvää, että se oikealla hetkellä on heidät ohjannut itsehillinnän kaitaista polkua kulkemaan. Ja me vaatimattomat kansalaiset, jotka sydämissämme suremme ja huolehdimme isänmaamme tulevaisuudesta, opetelkaamme vaikeana hetkenä jalon, rakkauden ohjaaman itsehillinnän vaikeata taitoa. Antakaamme ajattelemattomasta hätäilystä johtuvien sanojen kuolla huulillamme mitään vahinkoa tuottamatta. Tehkäämme työtä ja rukoilkaamme. (Kotiliesi 6/1945, 166-167.)

\section{ITSEHILLINTÄÄ JA YHTENÄISYYTTÄ \\ LUTERILAISEN KULTTUURIN VOIMALLA}

Yhteistä kaikille edellä esitetyille narratiiveille on niissä esiintyvä harras kristillisyys. Esimerkiksi Vaasa rohkaisi lukijoitaan välirauhan saavuttua seuraavasti: "Vaikka eilinen syyskuun 19. päivä oli kansallemme suuren murheen päivä, epätoivo ei saa silti asettua suomalaiseen elämään. Rohkeasti eteenpäin! Jumala ompi linnamme.” (Vaasa 20.9.1944, 2.) Kaleva kehotti pääkirjoituksessaan yhtymään "ministeri von Bornin loppulausuntoon sisältyneeseen vanhaan Saarijärven Paavon toteamiseen: 'Vaikka koetteleekin, eipä hylkää herra."” (Kaleva 20.9.1944, 2.)

Kuitenkin kaikista pisimmälle tämä kristillishenkinen asioiden käsittelytapa oli viety Kotiliedessä, joka käsitteli vuosien 1944-1945 aikana surua useaan otteeseen. Tämä ei kuitenkaan ole yllättävää, sillä Kotilieden arvomaailma oli tiukasti sidoksissa porvarillisen yhteiskunnan ihanteisiin, jossa uskonto muodosti tärkeän kollektiivisen tukipilarin.

Kotilieden ensimmäisessä numerossa aselevon astuttua voimaan "Isoäiti" kirjoitti surusta. Tosin kirjoitus oli todennäköisesti laadittu ennen aselepoa, ja aivan kuten hänen keskustelunsa itsehillinnästä kesällä 1944 myös keskustelu surusta aselevon jälkeen huokui kesän 1944 suurhyökkäyksen synkeitä - mutta tulevaisuuteen luottavia - tunnelmia: "Surulla on sanoma jokaiselle, se hiljentää, se pyhittää, se yhdistää, se luo uutta tarmoa ja uutta vastuuntuntoa." Isoäidin mukaan 


\section{JälLEENRAKENTAMISEN NARRATIIVIT JA NIIDEN MUOTOUTUMINEN SUOMEN LEHDISTÖSSÄ 1944-1945}

surumme ja huolemme ei saa olla lohdutonta, kuten niillä, jotka eivät tulevaisuutta näe. Meidän on uskon voimalla taisteltava eteenpäin niin yksityisinä ihmisinä kuin kansanakin, ja me tulemme kerran näkemään, että surunkin takana on rakkaus, joka nytkin ohjaa tietämme. (Kotiliesi 18/1944, 522.)

Surusta ja menetyksistä huolimatta oli Suomi rakennettava uudelleen, joten myös surusta oli löydettävä käyttövoimaa. Isoäiti kirjoittikin:

Jumala auttakoon sinua, jota suru painaa, Jumala auttakoon meidän isänmaatamme, joka on surun tuttu! Tahdommehan koettaa yhdessä oppia sanomaan: Minä uskon iänkaikkiseen elämään, minä uskon kansani elämään ja sen tehtävään Jumalan säätämällä tiellä. (Kotiliesi 18/1944, 522.)

Suomen sodissa kaatui noin 94000 (enimmäkseen nuorta) miestä. Voi olettaa, että kaatuminen kosketti lähes maan jokaista kotitaloutta tavalla tai toisella. Koska sota-ajan menetykset olivat Suomelle niin raskaat, voi tutkitun materiaalin perusteella sanoa, että myös surulle oli löydettävä isänmaallinen, kaatuneiden sotilaiden puolesta puhuva selitysmalli. Jatkosodan alun tunnelmissa, jolloin odoteltiin suur-Suomen sarastusta, uhrautuminen isänmaalle oli "hyväksyttävää, jopa etuoikeus" (Kemppainen 2006, 107). Vuonna 1944 tilanne oli jo ratkaisevasti muuttunut ja sankarikuoleman mielekkyys oli perusteltava tapahtumattomalla. Kotilieden "Sielunpaimen" ilmaisi asian suorin, purevin sanakääntein. Huomattakoon tosin, että kaatuminen oli yhä etuoikeus:

Paljon on nykyisissä katkerissa suruissa [...] lievittävää. Isänmaan asia ennen kaikkea [...] viime toukokuussa sanottiin eräällä suurella veljeshaudalla: 'Tämä päivä on kyllä surullinen päivä, ennen kaikkea tuhansille sureville omaisille, mutta vielä surullisempaa olisi maassamme tänä päivänä, ellei näitä hautoja olisi.” Elleivät näet miehemme olisi antaneet kaikkeaan, ei Suomessa enää olisi omia koteja, ei vapautta, ei tulevaisuutta. Kaiken hävittäisi ryöstävä, polttava, murhaava vainolainen. Siperiaan olisi tuhansien suomalaisten matka. (Kotiliesi 16/1944, 454.)

Isänmaan asia ennen kaikkea. Surussa piili lunastuksen ja uuden valon siemen, kuten "Sielunpaimenen" artikkeli jatkuu:

Raamatussa viitataan usein siihen puhdistavaan ja syventävään vaikutukseen, joka kärsimyksellä on. Kun luotamme otetaan isän ja äidin silmien ilo, heidän rakas lapsensa kukkeimmassa iässä, tapahtuu jäljellejääneiden kohdalla ihmeellinen uusi asennoituminen: turhuus näkyy turhaksi, maailmalliset päämäärät tuntuvat peräti vähäarvoisilta, ja ikuisuus tulee yht'äkkiä läheisemmäksi ja todellisemmaksi kuin koskaan tätä ennen $[\ldots]$

Kärsimykset, jotka meitä Jumalan sallimuksesta hänen lapsinaan kohtaa- 


\section{Antero Holmila}

vat, ovat ojennusta, puhdistusta, kuritusta. Ne ovat rakkautta. Ne tähtäävät suurempaan hedelmän kantamiseen.

On sanottu, että koti tulee siunatuimmaksi kodiksi silloin, kun joku sen jäsenistä on otettu edellä sinne toiselle puolelle [...] Nyt on tullut tuhansiin Suomen koteihin uusi armosiunaus. Kodeista on otettu pois hän, jota kukaan eikä mikään voi korvata. Mutta samalla tuli uusi, korvaamaton armo. (Kotiliesi 16/1944, 454-545.)

Kärsimyksen ja siihen liittyvän lunastuksen kautta oli Suomen tie vievä kohti uusia, parempia aikoja. Ken nöyrästi otti Jumalan kurituksen vastaan (kuten Paavo aikoinaan), kykeni tuntemaan todellisen rakkauden, rakkauden, jonka kokemisen mahdollisti vain läheisen sankarikuolema. Tällä tavoin omaisensa menettäneitä kannustettiin nöyrästi hyväksymään kohtalonsa. Kaiken lisäksi he olivat - ainakin sielunpaimenen kirjoituksen mukaan - etuoikeutetussa asemassa, koska vain he pystyivät kokemaan "uuden, korvaamattoman armon". Tällainen lunastuksen narratiivi tulee hyvin lähelle - eikä varmasti sattumalta - kansallisromanttista käsitystä Suomen historiallisesta asemasta valittuna kansana, joka on erityisen elävästi vallallaan Topeliuksen Maamme-kirjassa. Viimein on todettava, että Kotilieden ohjeistus oli osaltaan luomassa normatiivista tapaa käsitellä surua. Vaikka kuolema sodassa - sankarikuolema - oli sekä yksilöllinen että yhteisöllinen tragedia, sodanjälkeisessä konstruktiossa yksilön suru oli aina hierarkkisesti alistussuhteessa yhteisön tai isänmaan surun tasoon. Tässä kehässä surun hierarkkisen suhteen ylläpitäminen vaati kansalaisilta suurta itsehillintää.

\section{LOPUKSI}

Jälleenrakennuskertomus ja sen konstruktio muotoutuivat selviytymiskamppailuiksi, joissa dominoiviksi piirteiksi nousivat normatiivinen vaatimus kansan yhteisrintaman ja yhteishengen sällyttämisestä. Suomalaisessa lehdistössä voi havaita kolme erillistä, tosin toisiinsa limittyvää narratiivista konstruktiota, joiden avulla jälleenrakentaminen merkityksellistettiin: selviytyminen, uhrautuminen/velvollisuuden täyttäminen ja itsehillintä. Lehdistö oli osaltaan luomassa normatiivista viitekehystä, jonka voi kiteyttää seuraavasti: sodan vaatimat uhraukset olisivat olleet turhia, jos rauhan tultua maa hajoaisi sisäisiin ristiriitoihin.

Lopuksi on todettava, että miettimisen aiheeksi nousee perinteinen "ensimmäinen tasavalta" - "toinen tasavalta" -dikotomia, jonka mukaan jatkosodan tappioon päättyi ensimmäisen tasavallan eli valkoisen Suomen aika (ks. esim. Ylikangas 1986). Se valtaisa ensimmäisen tasavallan henkinen kasvatustyö, jolle nuori valtio oli ideologisesti pystytetty - koti, uskonto, isänmaa -symboliikka - näkyi lehdistön narratiivisissa konstruktioissa selvästi sodan jälkeen, vaikka ulkopoliittisesti - ja ulospäin - toinen tasavalta näyttäytyi varsin erilaisena yhteiskuntana. Kristian Smedsin Tuntemattoman sotilaan näytelmäversion aiheuttamaa kohua arvioineen Helsingin Sanomien kulttuuritoimittajan Saska Snellmanin mukaan Smedsin tulkinta oli "Linnalle hyvinkin uskollinen 
$[\ldots]$ viinapullon äärellä [...h]erra huomaa, ettei suomalaista voi johtaa pakolla, mutta työmieskin tajuaa, että ihminen se on herrakin. Juuri tälle pohjalle rakentui Suomen kansallinen sovinto, joka mahdollisti sodasta selviämisen, jälleenrakentamisen ja lopulta hyvinvointivaltion luomisen.” (30.11.2007, C9).

Kuten olen pyrkinyt osoittamaan tässä artikkelissa, nämä jälleenrakennuksen narratiivit, joihin myös Snellman viittaa termillään kansallinen sovinto, rakentuivat ensimmäisen tasavallan symboleiden ympärille, mikä tarkoitti jälleenrakennuksen sitomista jo ennestään vahvoihin symbolisiin merkitysjärjestelmiin. Tästä johtuen jälleenrakennusaika on muodostunut osaksi vahvaa suomalaista kulttuurijärjestelmää, joka ei kollektiivisella tasolla tee eroa kansallisromantiikan, sota-ajan ja sodanjälkeisen ajan välillä.

\section{VIITTEET}

1. Aino Voipio kirjoitti 1930-luvulla Kodin kasvatustyöstä-nimisen, WSOY:n kustantaman kaksiosaisen opassarjan, joka käsitteli varhaislapsuutta (osa I) ja myöhäisempää lapsuutta (osa II). Aikaisemmin, 1929, Otava oli julkaissut hänen teoksensa Grundtvigin nuorisokasvatusaatteesta. Tanskalainen N. F. S. Grundtvig (1783-1872) on yksi varhaisimmista kansanopisto-aatteen puolestapuhujista. Hänen mukaansa ylempien koulutustahojen tärkeimmän tehtävän tulisi olla opiskelijoiden muokkaaminen aktiiviseen yhteiskunnalliseen elämään sekä käytännöllisiä että akateemisia taitoja, kuten historian opetusta, vaalien.

\section{LÄHTEET}

\section{Tutkimusaineistot:}

Helsingin Sanomat (1.8.1944-1.3.1945; 27.9.2002; 1.11.2006; 30.11.2007 )

Suomen Kuvalehti (heinäkuu 1944-maaliskuu 1945)

Kotiliesi (heinäkuu 1944-maaliskuu 1945)

Suomen Sosialidemokraatti (1.9.1944-1.3.1945)

Kansan Työ (1.9.1944-15.12.1944)

Suomalainen Suomi (heinäkuu 1944-maaliskuu 1945)

Kaleva (1.9.1944-15.12.1944)

Savon Sanomat (1.9.1944-15.12.1944)

Karjalan Sanomat (1.9.1944-15.12.1944) 


\section{ANTERO HOLMILA}

\section{Kirjallisuus:}

ALASUUTARI, PERTTI 1996: Toinen tasavalta. Suomi 1946-1994. Tampere: Vastapaino,

BLOMSTEDT, YRJÖ \& KLINGE, MATTI (toim.) 1985: J .K. Paasikiven päiväkirjat 1944-1956. Ensimmänen osa 28.6.1944-24.4.1949. Porvoo: WSOY.

CONNERTON, PAUL 1989: How Societies Remember. Cambridge: Cambridge University Press.

ECO, UMBERTO 1984: Semiotics and the Philosophy of Language. Honkong: Macmillan.

ESKOLA, KATARINA 1987: Nykysuomalaisten suuret kertomukset. - Hoikkala, Tommi (toim.), Kieli, Kertomus, Kulttuuri. Helsinki: Gaudeamus.

HIETANEN, SILVO 1992: Aseista mottimetsään - armeijan kotiuttaminen syksyllä 1944. - Hietanen, Silvo (toim.), Kansakunta sodassa 3. Kuilun yli. Helsinki: Valtion painatuskeskus.

HUYSSEN, ANDREAS 1995: Twilight Memories: Marking Time in a Culture of Amnesia. New York: Routledge.

HYVÄMÄKI, LAURI 1954: Vaaran vuodet 1944-1948. Helsinki: Otava.

JANATUINEN, JENNI 2005: Miehenkuva. Kalle Päätalon perintö. Helsinki: Johnny Kniga Publishing.

JÄNTTI, LAURI 1983: Salainen sotapäiväkirjani. Jatkosota rintamakirjeiden ja kommenttien valossa. Porvoo: WSOY.

KALELA, JORMA 1993: Aika, historia ja yleisö. Turku: Turun yliopisto.

KANE, ANNE 2000: Reconstructing Culture in Historical Explanation: Narratives as Cultural Structure and Practice. - History and Theory 39(3).

KARONEN, PETRI \& TARJAMO, KERTTU (toim.) 2006: Kun sota on obi. Sodista selviytymisen ongelmia ja nïden ratkaisumalleja 1900-luvulla. Helsinki: Suomalaisen Kirjallisuuden Seura.

KEMPPAINEN, ILONA 2006: Isänmaan ubrit. Sankarikuolema Suomessa toisen maailmansodan aikana. Helsinki: Suomalaisen Kirjallisuuden Seura.

KINNUNEN, TIINA \& KIVIMÄKI, VILLE (toim.) 2006: Ibminen sodassa. Suomalaisten kokemuksia talvi- ja jatkosodasta. Jyväskylä: Minerva.

KOSKI, KAARINA 2007: Mikä kertomus on? Tieteidenvälisyyden haasteita "kertomusten" tarkastelussa. - Elore 14(1) [online]. <http://www.elore.fi/arkisto/1_07/ kos_c_1_07.pdf> [11.9.2008]

LOEWY, HANNO \& MOLTMANN, BERNHARD (eds.) 1996: Erlebnis-GedächtnisSinn: Authentische und konstruierte Erinnerung . Frankfurt: Campus Verlag. MINK, LOUIS 1978: Narrative Form as Cognitive Instrument. - Canary, R. H. \& Kosicki H. (toim.), The Writing of History. Madison: University Press of Wisconsin. MUNSLOW, ALUN 2003: The New History. Harlow: Pearson \& Longman. MYLLY, JUHANI 2002: Kansallinen projekti. Historiankirjoitus ja politiikea autonomisessa Suomessa. Turku: Kirja-Aurora. 
MÄKILÄ, KIMMO 2007: Tuhoa, tehoa ja tublausta. Helsingin Sanomien ja New York Timesin ydinaseuntisoinnin tarkastelua diskurssianalyyttisesta näkökulmasta 1945-1998. Jyväskylä: Jyväskylän Yliopisto.

PAAKKUNAINEN, KARI 1986: Suomalainen 'Staaträson' yöpäiväkirjana. Paasikiven muistiinpanojen lukutavoista ja valtio-opillisesta relevanssista. - Politiikeka 2.

PAAVOLAINEN, OLAVI 1946: Synkkä Yksinpubelu: Päiväkirjan lebtiä vuosilta 1941_ 1944. Keuruu: Otava.

PEKONEN, KYÖSTI 1991: Symbolinen modernissa politiikassa. Jyväskylä: Jyväskylän yliopisto.

RAUTKALLIO, HANNU 1990: Paasikivi vai Kekkonen. Suomi lännestä nähtynä. Helsinki: Tammi.

RICOEUR, PAUL 1978: The Language of Faith. - Reagan, Charles E. \& Stewart, David (eds.), The Philosophy of Paul Ricoeur: An Anthology of his Work. Boston: Beacon Press.

SALMINEN, ESKO 1979: Aselevosta kaappaushankkeeseen. Sensuurija itsesensuuri Suomen lebdistössä 1944-1948. Helsinki: Otava.

SEPPINEN, JUKKA 2008: Vaaran vuodet? Suomen selviytymisstrategia 1944-1950. Helsinki: Minerva.

SOMERS, MARGARET 1994: The Narrative Constitution of Identity: A Relational Network Approach. - Theory and Society 23(5).

USKALI, TURO 2003: "Älä kirjoita itseäsi ulos": suomalaisen Moskovan-kirjeenvaibtajunden alkutaival 1957-1975 [online]. <http://dissertations.jyu.fi/studhum/9513915433. pdf> [11.9.2008]

WHITE, HAYDEN 1990: The Content of the Form: Narrative Discourse and Historical Representation. Baltimore: John Hopkins University Press.

WODAK, RUTH 1996: Disorders of Discourse. London: Longman.

YLIKANGAS, HEIKKI 1986: Käännekohdat Suomen historiassa. Helsinki: WSOY.

Filosofian tohtori Antero Holmila toimii post doc -tutkijana Jyväskylän yliopiston historian ja etnologian laitoksessa. Artikkeli on valmistunut Koneen Säätiön tutkimushankkeessa "Joukkoviestimet ja rauhaan palaaminen. Sodan jälkitilat sähköisissä ja painetuissa viestimissä toisen maailmansodan jälkeen (n. 1944-1950)". 